\title{
Feed intake and production in dairy breeds dependent on the ration
}

\section{S. Korver}

Department of Animal Breeding, Agricultural University, Marijkeweg 40, 6709 PG Wageningen, the Netherlands

Accepted: 6 December 1983

\begin{abstract}
This study describes the variation in feed intake (energy and roughage) and production characteristics (milk production and composition, live weight) in dairy cattle for two subpopulations dependent on the ration. The importance of the genotype-ration interaction for these characteristics was also tested.
\end{abstract}

Key-words: feed intake, milk production, breed, ration, genotype-ration interaction.

Introduction. In the early stages of lactation the intake of nutrients, especially energy and protein, does not meet the requirements of the high-yielding cow. The gap between supply and demand can be reduced by either increasing the concentration of the ration, increasing the feed intake or by a combination of these two factors. The extent, in practice, to which the concentration can be increased is limited because approximately $30 \%$ of the dry matter should be from long roughage to enable the rumen to function normally. To increase milk yield may also require changes in forage consumption, possibly to cows with larger rumen capacity. Little information exists regarding variation among animals in either total or forage intake (Miller et al., 1972; Freeman, 1975) and especially on feeding systems in which the level of concentrates is independent of the milk yield. Most studies have been carried out on feeding regimes with concentrates given according to milk production. Both characteristics were confounded in that situation.

The present selection is based on performance on a high concentrate level. Environmental circumstances such as nutrient supply (roughage/concentrates) may be changed and the mechanisms for regulating the feed intake may vary according to its digestibility (Conrad et al., 1964). In addition, the import of semen from Holstein Friesians is increasing in the Netherlands. The Dutch Friesians and the Holstein Friesians show a genetic difference for milk production (Oldenbroek, 1981) and the subpopulations were selected in different environmental circumstances. However the importance of the interaction between genotype and ration in temperate zones was only studied within a breed (e.g. Richardson et al., 1981; Lamb et al., 1977). 


\section{S. KORVER}

Material and methods. The objectives were studied in an experiment over two successive lactations and in the dry period between these two experiments. The two breeds were characterized as Dutch Friesian (DF) and the crosses between Holstein- and Dutch-Friesians (50 and $75 \%$ ) (HF). In the first experimental lactation the cows were in their second or later lactation.

The rations contained roughage ad libitum. The amount of concentrates was independent of the milk production and restricted to the treatment. A low (roughage group) and high concentrate level (concentrate group) were used with total concentrate intakes per lactation of 570 and $2310 \mathrm{~kg}$ respectively. The carry-over effects from the first to the second experimental lactation were studied on a ration change for all the individuals.

Full lactation data were analysed from 91 cows in the first and 64 cows in the second experimental lactation.

Results. The energy intake of the roughage groups in the first and second experimental lactations was $21 \%$ and $27 \%$ lower than that of the concentrate groups. The contrasts for the roughage dry matter intake were $22 \%$ (overall mean: $11.7 \mathrm{~kg}$ per day) and $17 \%$ (overall mean: $11.5 \mathrm{~kg}$ per day) in favour of the roughage groups. The carry-over effect was shown in the second experiment but the ration effect of the first lactation was not significant during the dry period (the same concentrate level for all the cows).

The breed effect was significant $(P \leqslant 0.05)$ only at the end of both lactations and the contrasts between $\mathrm{DF}$ and $\mathrm{HF}$ groups for roughage intake were $-4 \%$ and $-5 \%$ respectively.

The interaction between breed and ration was not significant $(P \leqslant 0.05)$. The coefficient of variation (adjusted for number of lactation, season and days open) for roughage dry matter intake was approximately $8 \%$.

The contrasts between the two breeds (DF - HF) for milk production in the two lactations were $-594(10.1 \%)$ and $-407 \mathrm{~kg}(7.2 \%)$ respectively. In the preceding lactations the individuals were offered concentrates according to milk yield. The analysis of variance of the preceding lactation resulted in a contrast between genotypes of $-974 \mathrm{~kg}(15.2 \%)$. The coefficients of variation adjusted within the genotype-ration group also showed a decrease on a feeding regime with concentrate independent of the milk production.

The HF groups had lower fat and protein percentages in the milk. These results caused the contrasts for the milk energy equivalence to be smaller than for milk yield (contrasts: 7.7 and $3.7 \%$ ).

The ration had a clear effect on the milk yield and the milk energy equivalence in the two lactations (ca. $20 \%-1250 \mathrm{~kg}$ ). A carry-over effect for milk yield was shown at the beginning of the second experimental lactation but it was compensated at the end.

The genotype-ration interaction was not significant $(P \leqslant 0.05)$ for the total milk production characteristics nor generally during the lactation.

The efficiency in terms of the ratio of milk energy equivalance to energy intake showed a significant ration effect at the beginning of the lactation. This was caused 
by a difference in live weight change between the two rations. The difference between breeds was approximately $4 \%$.

The efficiency and the milk energy equivalence were highly correlated with a difference between rations. The concentrate level and the allocation of concentrates to individuals have an influence on the relationships. Estimates of genetic parameters on different feeding systems are necessary for predicting the response to selection in different environments.

\section{References}

Conrad, H. R., A. D. Pratt \& J. W. Hibbs, 1964. Regulation of feed intake in dairy cows. 1. Change in importance of physical and physiological factors with increasing digestibility. Journal of Dairy Science 47: 54-62.

Freeman, A. E. 1975. Genetic variation in nutrition of dairy cattle. In: The effect of genetic variation on nutrition requirements of animals, Washington: 19-46.

Lamb, R. C., J. L. Walters, M. J. Andersen, R. D. Plowman, C. H. Mickelsen \& R. H. Miller, 1977. Effects of sire and interaction of sire with ration on efficiency of feed utilization by Holsteins. Journal of Diary Science 60: 1755-1767.

Miller, R. H., N. W. Hooven, J. W. Smith \& M. E. Creegan, 1972. Feed consumption differences among lactating cows. Journal of Dairy Science 55: 454-459.

Oldenbroek, J. K.. 1981. Economic evaluation of breed comparison. 32th Annual Meeting European Association for Animal Production, Zagreb.

Richardson, D. O., J. R. Owen, R. D. Plowman \& J. T. Miles, 1971. Importance of sire $\times$ ration interactions in production and feed intake traits of dairy cattle. Journal of Dairy Science 54: 1518-1525.

This synopsis is based on a doctoral thesis, Agricultural University, Wageningen, 1982. 148 pp., 22 figs, 61 tables, 6 appendices, 110 refs. English, Dutch summary.

Available as paper copy (order R002P, $f 30$ including postage) or microfiches (order R002M, $f$ 17,50 including postage) at: NARD, clo Pudoc, P.O. Box 4, 6700 AA Wageningen, Netherlands (telex $45015 \mathrm{blhwg} \mathrm{ll}$ ).

\section{Development of improved wheat genotypes in Zambia using incomplete resistance against rusts}

W. A. J. de Milliano (Guest, Department of Phytopathology, Agricultural University, Wageningen, Netherlands)

Accepted: 16 December 1983

Abstract. A low-budget breeding programme was used for developing fairly highyielding wheat lines within 6 years. The lines had a stable and incomplete resistance 